\title{
Tataran Fonem Penderita Afasia Broca pada Produksi Leksikal: Suatu Kajian Neuro-Fonologi
}

\author{
Mhd. Johan ${ }^{1)}$, Triyani Tami ${ }^{2)}$ \\ thorshid@gmail.com ${ }^{1)}$, tami.upb@gmail.com ${ }^{2)}$ \\ Program Studi Pendidikan Bahasa Indonesia, Universitas Putera Batam, Indonesia
}

\begin{abstract}
Abstrak. Penelitian ini adalah penelitian lapangan yang beraliran linguistik terapan dengan melakukan pendekatan neuro-fonologi. Tujuan penelitian ini adalah untuk menjelaskan bentuk leksikal yang diproduksi oleh penutur. Menjelaskan bagaimana proses ujaran fonem yang dituturkan oleh penderita afasia broca. Penulis juga menggunakan pendekatan fonologi dan pendekatan morfologi. Adapun pengumpulan data pada penelitian ini yakni dengan menggunakan metode simak libat cakap. Pada metode ini peneliti terlibat aktif memancing responden untuk bicara sebanyak-banyaknya sehingga didapatkanlah data yang lengkap dan dapat dianalisis dengan baik. Setelah melakukan penyadapan, peneliti mulai mencatatnya dan menyimpan data tersebut. Penulis menggunakan metode distribusi untuk menganalisis data tersebut. Metode tersebut didukung oleh teknik dasar bagi unsur langsung. Teknik itu seperti: teknik lesap, teknik ganti, dan teknik tambah. Adapun hasil yang didapat yakni ditemukan tiga gangguan dalam bertutur, gangguan tersebut meliputi proses penambahan, proses ganti, dan proses penghilangan.
\end{abstract}

Kata kunci: afasia broka, neurolinguistik, fonologi

\section{Pendahuluan}

Bahasa adalah simbol komunikasi yang digunakan manusia untuk menyampaikan pendapat pada lawan tuturnya. Dengan menggunakan bahasa sebagai media komunikasi manusia bisa memperoleh ilmu pengetahuan dari orang lain maupun bangsa lain, sehingga membuat ilmu pengetahuan dapat berkembang dengan baik keseluruh penjuru dunia.

Bahasa yang digunakan oleh manusia tidak selalu dapat dimengerti oleh lawan tuturnya. Dalam penelitian Johan (2016) mengatakan bahwa pengguna bahasa sering mengalami masalah dalam memahami makna selama dalam komunikasi sehingga pendengar dan penutur sangat membutuhkan ilmu bahasa. Sehingga maksud yang disampaikan tidak tercapai dan pendengar gagal memahami maksud yang dimaksudkan penderita. Dengan adanya peristiwa ini penulis berusaha untuk membantu para pengguna bahasa untuk memahami para pengguna bahasa.

Gagal paham terhadap bahasa sering terjadi pada penederita afasia, disartria dan anakanak. Di sini penderita mengalami masalah dalam memproduksi leksikal. Leksikal yang mereka hasilkan tidak sesuai dengan yang diharapkan. Dalam bertutur, salah satu fonem yang dihasilkan oleh penutur dapat saja berganti sehingga maknapun menjadi berubah. Johan (2017) mengatakan dalam penelitian bahwa peristiwa tutur dapat terjadi pada beberapa hal, pertama terjadinya pelesapan dalam memproduksi fonem seperti pada leksikal /lari/ menjadi /lai/, hal lainnya juga dapat terjadi seperti proses ganti pada saat memproduksi leksikal /bisa/ 
menjadi /bica/. Proses selanjutnya seperti penambahan fonem pada leksikal /banyak/ menjadi /bannyak/.

Dan hal lainnya adalah ketidakberaturan dalam memproduksi leksikal. Diantara masalah itu, masalah yang paling dominan dialami penutur terdapat pada peristiwa ganti. Di samping Trost \& Canter (1974) dalam penelitiannya juga menemukan peristiwa ganti yang paling dominan yang dialami oleh penderita gangguan berbahasa. Peneliti lainnya Aichert, Späth, \& Ziegler (2016) juga menemukan hal yang sama dalam penelitiannya. Biasanya pergantian seperti ini terjadi pada lingkungan yang sama (Johan, Susanto, 2018). Kemudian Johan, Susanto, (2018) mengatakan bahwa peristiwa ganti yang terjadi dalam satu lingkungan disebut juga dengan asimilasi.

Sebenarnya penelitian seperti ini adalah penelitian lanjutan, yang pernah peneliti lakukan sebelumnya. Penelitian ini perlu dilanjutkan karena peneliti ingin para pengguna bahasa dapat memahami bahasa para penderita bahasa yang dilakukan oleh penuturnya. Sehingga terjadilah saling pengertian satu samalainnya. Penderita bahasa sangat tersinggung apabila bahasa yang diproduksinya tidak dapat dipahami oleh lawan tuturnya.

Pengguna bahasa yang mengalami masalah dalam memproduksi leksikal dapat saja terjadi pada setiap manusia apalagi pada penderita strok, anak-anak, dan lainnya. Sastra (2014) mengatakan bahwa orang yang mengalami masalah dengan leksikal telah terjadi suatu gangguan pada otak sebelah kiri penderita dimana otak kiri itu adalah tempat bahasa itu diproduksi.

Gangguan berbahasa dapat terjadi pada masalah disartria maupun masalah afasia broka. Sastra (2010) mengatakan bahwa gangguan disartria itu adalah dimana para penderita mengalami masalah dalam memproduksi leksikal. Sedangkan penderita afasia mengalami masalah dalam memproduksi gabungan kata atau dalam membuat kalimat. Memang agak sulit membedakan kedua gangguan tersebut. Tapi setelah melakukan pengamatan yang lebih dalam dan teliti peneliti berusaha untuk menguraikan dan menganalisisnya dengan tajam berdasarkan pengamatan peneliti.

Setiap penutur yang mengalami gangguan dalam memproduksi leksikal yang terjadi dalam komunikasi tidak dapat dipisahkan dari kasus neurolinguistik. Ahlsen (2006, p. 3) dalam bukunya mengatakan bahwa gangguan komunikasi adalah kasus neurolinguistik dimana otak sangat berperan dalam melakukan bahasa.

Leksikal yang diproduksi oleh penutur sangat berhubungan dengan kajian kajian fonologi maka dari itu peneliti sengaja mengkombinasikan penelitian ini dengan neurolinguistik. Kedua ilmu ini akan saling mendukung satu sama lainnya. Dan ilmu ini dapat dijadikan sebagai bahan utama dalam penelitian ini.

Selanjutnya Leung, Purdy, Tippett, \& Leão (2017) mengatakan bahwa leksikal merupakan hal yang terpenting dalam berkomunikasi, fonologi dan neurolinguistik mendapat tempat yang terdepan tahap menganalisis masalah yang timbul dalam berkomunikasi. Dan hal ini tidak dapat dipisahkan makna yang tercipta nantinya, kajian hal seperti ini termasuk ke dalam gangguan disartria atau afasia (Polanowska \& Pietrzyk-Krawczyk, 2016).

Kemudian Aichert et al. (2016) dalam jurnalnya mengatakan juga, disartria dan afasia merupakan gangguan yang dialami oleh penutur yang terdapat pada motor bicara penutur 
dalam bertutur. Jadi setiap tuturan yang diproduksi oleh penutur disartria perlu dilihat dan diperhatikan pada saraf bicara penutur.

\section{Metode}

\section{Teknik Pengumpulan Data}

Untuk mengumpulkan data, researcher pada penelitian ini menggunakan Metode simak libat cakap (SLC). Cara ini sangat pantas digunakan, di mana, peneliti ikut terlibat dalam memancing responden untuk bicara sebanyak-banyaknya, kemudian peneliti merekam ujaran yang diujarkan oleh responden secara diam-diam. Kenapa dilaksanakan secara diamdiam atau rahasi, hal ini bertujuan keaslian tuturan yang dituturkan oleh responden dan untuk menghindari masalah psikologi terhadap penderita.

\section{Teknik Lanjutan}

Teknik lanjutan mempunyai beberapa tahapan. Tahapan itu terdiri dari teknik simak libat cakap, teknik rekam, dan teknik catat. Pada teknik ini peneliti terlibat aktif untuk mengungkap dan memancing semua tuturan yang akan dituturkan oleh responden sehingga terjadilah hasil yang maksimal. Perekaman dilakukan dengan menggunakan handphone VIVO Y15 yang dimiliki. Setelah proses dilaksanakan barulah dilakukan pencatatan dan menyimpannya di labtop peneliti.

\section{Metode dan Teknik Analisis Data}

Untuk menganalisis data ini maka peneliti menggunakan metode distribusi dan dilanjutkan dengan teknik dasar dan teknik lanjutan, seperti teknik penambahan, teknik ganti, dan teknik lesap oleh (Sudaryanto., 2015).

\section{Subjek Penelitian}

Subjek yang dimaksud adalah penelitian kualitatif, subjek dari research ini adalah penderita yang mengalami masalah dalam melafalkan fonem yang digunakan dalam wicara setiap harinya.

\section{Data dan Sumber Data}

Adapun data yang diambil adalah tuturan seseorang. Pada tuturan tersebut ada leksikal, fonem dan bagaimana prosesnya. Pada proses tersebut akan kelihatan peristiwa-peristiwa pelesapan, penambahan, dan pergantian.

\section{Hasil dan Pembahasan}

\section{Bentuk Tuturan Leksikal Responden}

Pada penelitian ada beberapa hal yang perlu diketahui, diantaranya bagaimana proses fonem yang dilafalkan oleh responden, berada pada posisi mana fonem yang diproduksi oleh penutur, dan bagaimana pengaruhnya terhadap morfem yang diproduksi. Data 1 (bahasa Minang)

Tabel 1 Data Responden1

\begin{tabular}{lllll}
\hline No & Bentuk Ujaran & Maksud & Makna dalam Bahasa & Keterangan \\
\hline 1 & tau & tau & Tau & \\
2 & wak & awak & Saya &
\end{tabular}




\begin{tabular}{lllll}
3 & ai & lai & Ada & Pengurangan \\
4 & tih & pitih & Uang & Pengurangan \\
5 & abis & abis & Habis & \\
6 & bali & bali & Beli & \\
7 & ado & ado & Ada & \\
8 & do & duo & Dua & \\
9 & juta & juta & Juta & \\
10 & hono & honor & Honor & Pengurangan \\
11 & kaate & karate & Karate & Pengurangan \\
12 & keja (ind) & kerja & Kerja & Pengurangan \\
13 & mana & mana & Di mana & \\
14 & keja (ind) & kerja & Kerja & Pengurangan \\
15 & aaiuo & baduo & Berdua & Ganti \\
\hline
\end{tabular}

Pada tabel di atas kelihatan bahwa terdapat lima belas morfem yang diproduksi oleh responden, dari lima belas morfem itu terdapat delapan morfem yang tidak dapat dilafalkan dengan baik dan sempurna. Dari delapan morfem itu, proses pengurangan lebih dominan dialami oleh responden ini.

Proses pengurangan pertama yang dialami adalah ketika responden melafalkan morfem /lai/ sementara /lai/ berarti /ada/. Pada saat melafalkan ini responden menuturkan /ai/. Sementara makna /ai/ dalam bahasa minang tidak ada dijumpai. Dapat dikatakan tuturan itu tidak bermakna. Pada lima belas morfem yang diujarkan responden terdapat dua bunyi 2 alveolar languid lateral plain /l/ bunyi yang pertama terjadi pada saat melafalkan /lai/ sedangkan yang kedua pada /bali/ yang berarti /beli/.

Pada saat memproduksi dua morfem tersebut terjadi dua posisi alveolar. Posisi yang pertama terjadi pada silaba pertama pada morfem /lai/ sedangkan untuk posis alveolar kedua terjadi pada posisi silaba kedua pada morfem /bali/. Jadi dapat disimpulkan bahwa responden ini mengalami masalah dalam melafalkan bunyi alveolar /l/ pada silaba pertama.

Proses pengurangan selanjutnya terdapat pada saat menuturkan morfem /pitih/. Pada saat menuturkan morfem ini responden tidak dapat menuturkannya dengan sempurna, sehingga dia menuturkan/tih/ saja. Dalam bahasa Minang makna/tih/ tidak ada dijumpai, kalau /tih/ ini diberi awalan seperti /pi/ dan /pu/ barulah melekat maknanya.

Melihat dari kontek pembicaraan makna (pragmatik) dapat diketahui maknanya bahwa sipenutur melafalkan/pitih/ yang berarti uang. Untuk prefik yang kedua /pu/ penulis rasa konteks pembicaraannya bukan mengarah ke warna. Melainkan ke biaya pengobatan responden yang jumlahnya lumayan banyak. Sehingga responden mengatakan tih tak ado yang bermakna pitih tak ado.

Pengurangan yang berikut terjadi pada saat responden melafalkan /duo/ yang berarti /dua/. Pada saat melafalkan morfem ini responden tidak dapat melafalkannya sesuai yang diharapkan. Adapun hasil dari ujaran yang diujarkannya adalah /do /atau /do/. Berdasarkan peta bunyi vokal fonem /u/ dan /o/ berada pada posisi belakang seperti gambar di bawah ini. 
Tabel 2 Deskripsi Bunyi Vokal Belakang

\begin{tabular}{lc}
\hline \multicolumn{2}{c}{ Belakang } \\
$\mathrm{Tb}$ & $\mathrm{b}$ \\
\hline Tinggi & $\mathrm{u}$ \\
& $\mathrm{U}$ \\
Tengah & $\mathrm{o}$ \\
& $\mathrm{o}$ \\
Rendah & \\
Tb = tidak bundar, $\mathrm{b}=$ bundar &
\end{tabular}

Jadi terjadinya penghilangan bunyi / $\mathrm{d} /$ dapat diakibatkan oleh kesamaan lingkungan dalam peta artikulasi bunyi sehingga hal itu dapat saja produksi bunyi yang dituturkan oleh responden terjadi proses penghilangan dan dapat juga terjadi peristiwa ganti. Lingkungan tersebut berada pada posisi belakang bundar.

Penghilangan bunyi alveolar /r/, peristiwa bunyi ini terjadi pada dua posisi, kedua posisi itu terjadi pada area tengah, dan belakang. Pada pelafalan alveolar ini responden selalu gagal dalam memproduksinya. Hal itu terjadi pada pelafalan morfem /honor/, /karate/, /kerja/, dan /kerja/.

Pada preoses penghilangan morfem tersebut dapat dilihat pada kata di bawah ini.

/honor/ > /hono/, /karate/ > /kaate/, /kerja/ > /keja/, /kerja/ > /keja/

Terjadinya proses penghilangan tersebut masih dapat dimengerti oleh lawan tutur, hal itu disebabkan tidak adanya perubahan makna atau munculnya makna baru setelah terjadi penghilangan fonem. Dengan kata lain, alveolar /r/ maka tidak bertanggung jawab atas peristiwa ini.

Bunyi /aaiuo/ yang berarti /baduo/ (bahasa Minang) dalam bahasa Indonesia /berdua/. Pada peristiwa ini terjadi peristiwa ganti. Peristiwa ganti pertama terjadi pada prefik /b/ (bilabial voiced) menjadi /a/ sedangkan proses ganti berikut terjadi pada /i/ menjadi /d/ (alveolar voiced).

Yang terjadi seperti table di bawah ini.

Tabel 3 Peristiwa Ganti Vokal

\begin{tabular}{llrrr} 
& \multicolumn{2}{c}{ Depan } & \multicolumn{2}{c}{ Pusat } \\
& $\mathrm{Tb}$ & $\mathrm{b}$ & $\mathrm{Tb}$ & $\mathrm{b}$ \\
\hline Tinggi & $\mathrm{i}$ & & & \\
Tengah & & & & \\
Rendah & & & & $\mathrm{a}$ \\
\hline
\end{tabular}

Tabel 4 Peristiwa Ganti Konsonan

\begin{tabular}{lll}
\hline & bilabial & alveolar \\
\hline Voiced & $\mathrm{b}$ & $\mathrm{d}$ \\
\hline
\end{tabular}

Mengamati dua tabel di atas, pada pelafalan bunyi /baduo/ (bahasa Minang) yang berarti /berdua/ dimana bunyi voiced /b/ bilabial dan voiced /d/ alveolar berganti dengan /a/ pusat rendah dan vokal /i/ depan tinggi berganti dengan /d/ alveolar voiced.

Jadi dalam hal ini bunyi /a/ tidak bertanggung jawab terhadap perubahan fonem selain /b/ bilabial voiced dan sedangkan bunyi /i/ tinggi depan tidak bulat tidak bertanggung 
jawab terhadap perubahan bunyi lain selain /b/ bilabial voiced. Persentase Penghilangan Bunyi adalah sebagai berikut:

Tabel 5 Persentase Penghilangan Bunyi

\begin{tabular}{llll}
\hline & Banyak Peristiwa & Proses Peristiwa & Hasil \\
\hline Depan & 2 kali & $2 / 7 \times 100 \%$ & $29 \%$ \\
Tengah & 4 kali & $4 / 7 \times 100 \%$ & $57 \%$ \\
Belakang & 1 & $1 / 7 \times 100 \%$ & $14 \%$ \\
Total & & & $100 \%$ \\
\hline
\end{tabular}

Peristiwa-peristiwa pada tabel tersebut dapat digambarkan seperti pada diagram di bawah ini.

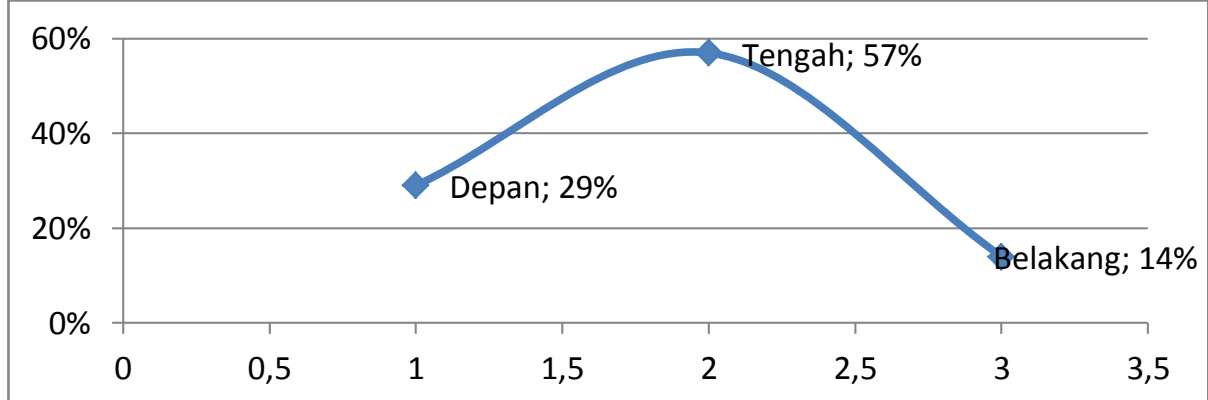

Gambar 4.1 Diagram Bertutur pada Responden 1

Pada tabel di atas kelihatan sekali peristiwa pelesapan pada posisi tengah lebih dominan terjadi hal ini disebabkan oleh fonem alveolar /r/ lebih dominan diujarkan. Sedangkan untuk pelesapan kedua terjadi pada posisi depan, fonem yang tidak dapat diujarkan berada pada posisi depan seperti /1/ dan /p/. Fonem /1/ adalah alveolar liquid lateral plain, dan sedangkan /p/ adalah stop plain bilabial voiceless.

\section{Proses Pembentukan Fonem yang Diproduksi oleh Responden}

Tabel 6 Data Responden 2

\begin{tabular}{llll}
\hline No & Bentuk Tuturan & Maksud Penutur & Keterangan \\
\hline 1 & kiRisten & kristen & Tambah dan ganti \\
2 & Ama & agama & Pengurangan \\
3 & Iisten & kristen & Ganti dan kurang \\
4 & au & tau & kurang \\
5 & mayama & sama & Ganti dan tambah \\
6 & ua-ua & dua-dua & kurang \\
7 & samaja & Sama saja & kurang \\
8 & ngngak & nggak & ganti \\
9 & angngak & Tidak/nggak & Tambah dan ganti \\
10 & mangabal & ikhbal & Ganti \\
\hline
\end{tabular}

Pada tabel di atas terdapat tiga peristiwa, peristiwa itu adalah peristiwa tambah, peristiwa ganti, dan peristiwa kurang.

Peristiwa tambah adalah suatu peristiwa dimana responden menambahkan menambahkan fonem-fonem terhadap morfem yang dilafalkan sehingga makna yang ditimbulkan menjadi tidak jelas dan kadang-kadang membuat makna baru. Adapun peristiwa tambah yang muncul di sini adalah: Kristen menjadi KiRisten, Sama menjadi Mayama, Nggak menjadi angngak 
Pada saat melafalkan morfem Kristen responden tidak dapat melafalkan morfem itu dengan benar yang sesuai dengan standar pelafalannya, sehingga responden lebih cenderung menyebutnya dengan kiRisten. Di sini dapat dilihat fonem yang ditambahkan adalah /i/ setelah fonem $/ \mathrm{k} /$. Menurut aturannya tidak demikian, akan tetapi penambahan pada fonem /i/ pada morfem kristen tidak menimbulkan makna baru. Dalam ilmu neurolinguistik hal seperti ini dianggap suatu gangguan artikulasi yang disebabkan oleh syaraf penderita sehingga mempengaruhi cara tutur responden.

Mayama adalah tuturan responden yang disampaikan kepada lawan tuturnya. Adapun maksud dari kata itu adalah "sama". Pada tuturan itu telah terjadi penambahan /ma/. Penulis sudah berusaha untuk mencari bunyi yang paling dekat dengan makna yang dituturkan oleh responden tetapi tidak dipernah dijumpai. Setelah dianalisis penulis menemukan maksud dari tuturan tersebut. "Mayama" artinya "sama".

Morfem /nggak/ ketika responden melafalkannya, morfem ini maknanya "tidak" jadi ketika responden melafalkan fonem tersebut terjadi /angngak/atau /ayya'/ dalam hal ini terjadi dua peristiwa. Peristiwa itu adalah proses penambahan dan proses ganti. Proses penambahan akan dianalisis pada bagian ini, sedangkan proses ganti akan dilakukan pada bagian proses ganti. Proses penambahan pertama terjadi pada silabel pertama yaitu dengan menambahkan vokal /a/ pusat rendah sedangkan penambahan kedua terjadi pada bunyi /ng/ atau $/ \mathrm{y} /$ velar nasal voiced yang terjadi pada silaba kedua.

Peta bunyi responden dapat dilihat pada tabel di bawah ini.

Tabel 7 Peta Bunyi Responden Non Vocoid dan Non Syllabic

\begin{tabular}{|c|c|c|c|c|c|}
\hline & Bilabial & Alveolar & Palatal & Velar & Uvular \\
\hline Stop & & $\mathrm{t}$ & & $\mathrm{k}$ & \\
\hline $\mathrm{v}$ & $\mathrm{b}$ & & & & \\
\hline Afrikatif $v$ & & 3 & & & \\
\hline Central v & & $\mathrm{s}$ & & & \\
\hline Nasal $\quad \mathrm{v}$ & $\mathrm{m}$ & $\mathrm{n}$ & & $\mathrm{y}$ & \\
\hline Trill & & & & & $\mathrm{R}$ \\
\hline Lateral plain & & 1 & & & \\
\hline Liquid & & & & & \\
\hline Glide plain & & & $\mathrm{y}$ & & \\
\hline
\end{tabular}

\begin{tabular}{lll}
\multicolumn{3}{c}{ Tabel 8 Vocal syllabic } \\
\hline & Depan & Tengah \\
\hline Tinggi & i & \\
Sedang & e & \\
Rendah & & a \\
\hline
\end{tabular}

Pasangan bunyi yang mencurigakan:

/n/ dan /y/, /i/ dan /e/

Bunyi yang tidak mencurigakan

/b/, /m/, /t/, /3/, /s/, /y/, /k/, /R/, dan /a/.

Prosedur Pemisahan 1

/r/ dan /R/

Perbedaan fonetis: /r/ adalah alveolar liquid rhotic plain, /R/ adalah uvular trill Lingkungan yang paling mirip 
/kristen/ dan /kiRisten/

Peta bunyinya

Tabel 9 Peta Bunyi yang mirip antara /Kristen/ dan /kiRisten/ Non Vocoid dan Non Syllabic

\begin{tabular}{llcc}
\hline \multicolumn{1}{c}{ voiceless } & Alveolar & Velar & \\
Stop $\quad$ voiced & & $\mathrm{k}$ & \\
Fricative & $\mathrm{s}$ & & \\
Central voiceless & & $\mathrm{R}$ & \\
Nasal & $\mathrm{n}$ & & \\
Trill & $\mathrm{r}$ & & \\
Liquid rhotic plain & & & \\
\hline
\end{tabular}

Tabel 10 Vokal syllabic

\begin{tabular}{lllll}
\hline & Depan & & Pusat & \\
& $\mathrm{Tb}$ & $\mathrm{b}$ & $\mathrm{Tb}$ & $\mathrm{b}$ \\
\hline Tinggi & $\mathrm{i}$ & & & \\
Tengah & $\mathrm{e}$ & & ə & \\
\hline
\end{tabular}

Hipotesa

Bunyi deret konsonan /k/ dengan alveolar /r/ selalu tidak dapat dilafalkan secara bersamaan.

Prosedur pemisahan 2

/g/ dan /y/

Perbedaan fonetis

/g/ adalah velar stop plain voiced dan / $\mathrm{y} /$ adalah velar nasal voiced

Lingkungan yang paling mirip

/nggak/ atau/ngak/, /ngngak/ atau/nyak/

Tabel 11 Peta Bunyi Konsonan /ngngak/ dengan /nggak/

\begin{tabular}{cl} 
Velar \\
\hline voiceless $\mathrm{k}$
\end{tabular}

Stop

Voiced $\mathrm{g}$

Nasal voiced $\quad \mathrm{y}$

Hipotesa: Bunyi deret konsonan velar nasal voiced / $\mathfrak{y} /$ dengan velar stop voiced tidak pernah dapat diujarkan secara bersamaan.

Proses berikutnya adalah proses ganti. Proses ini adalah salah bagian terpenting dalam analisis ini. Adapun morfem ganti yang diproduksi oleh responden adalah sebagai berikut.

/kristen menjadi /kiRisten/, /kristen/ menjadi /iisten/, /nggak/ menjadi /ngngak/, /nggak/ menjadi /angngak/, /sama/ menjadi /mayama/.

Pada saat menuturkan morfem Kristen menjadi KiRisten di sini kelihatan bahwa dua proses. Proses itu adalah tambah dan ganti, proses tambah sudah dibahasa pada bagian pertama, sedangkan proses ganti pada fonem alveolar liquid rhotic plain /r/ menjadi uvular 
trill /R/. Kelihatan pada produksi tuturan, responden tidak dapat melafalkan bunyi deret konsonal /k/ dengan /r/. Pergantian ini adalah pergantian satu ruang lingkup.

Sementara itu produksi morfem /Kristen/ juga gagal dilafalkan oleh responden sehingga menghasilkan bunyi /iisten/. Di sini kelihatan fonem /k/ stop velar, hal ini dapat diakibatkan oleh bunyi alveolar liquid rhotic plain tadi. Sehingga produksi bunyi yang lain menjadi terganggu.

Produksi bunyi berikutnya adalah /nggak/ menjadi /ngngak/, pada produksi bunyi ini juga terganggu, pada bunyi ini terdapat dua deret konsonan, konsonan itu adalah nasal voiced velar $/ \mathrm{y} /$ dan velar stop voiced /g/. Pasangan bunyi ini dapat saja terjadi karena mereka berada pada satu area, area itu terjadi pada area velar.

Proses pergantian berikut terjadi pada morfem /lkbal/, pada produksi tuturan ini responden mengalami masalah. Masalah tersebut terjadi pada posisi antepenultima, bunyi /i'/ berubah menjadi bunyi /manga/. Jadi posisi /i'/ tidak dapat dilafalkan dan hal itu telah terjadi dua silaba $/ \mathrm{ma} / \mathrm{dan} / \mathrm{na} /$. Perubahan tersebut terjadi pada posisi antepenultima yaitu fonem /i'/ berubah menjadi /mana/.

Pada morfem /sama/ terjadi dua peristiwa, peristiwa itu meliputi tambah dan ganti. Tapi di sini lebih fokus ke proses ganti. Pada pelafalan /sama/menjadi /mayama/, bunyi /s/ alveolar fricative central voiceless telah berganti menjadi /y/, /y/ adalah palatal liquid glide plain.

Peristiwa yang terakhir dari tuturan responden ini adalah pengurangan. Adapun morfem yang diproduksi responden adalah sebagai berikut:

/agama/ menjadi /ama/, /kristen/ menjadi /iisten/, /tau/ menjadi /au/, /dua-dua/ menjadi /ua-ua/, /sama saja/menjadi /samaja/

Pada saat memproduksi morfem lagama/ telah terjadi proses pengurangan. Pengurangan itu terjadi pada posisi penultima, yaitu pada bunyi /ga/, /ga/ adalah penultima pada morfem /agama/.

Sebenarnya morfem yang diproduksi oleh responden tidak memiliki makna, akan tetapi peneliti memahaminya dari ujaran morfem /Kristen/, Kristen mengacu pada agama yang dianut oleh umat nasrani.

Ujaran yang mengalami penghilangan berikut terjadi pada morfem /Kristen/. Pada saat melafalkan morfem ini responden mengujarkannya dengan /iisten/. Pada saat melafalkannya terjadi penghlangan fonem $/ \mathrm{k} /$ velar voiceless. Menurut analisis penulis hal ini dapat dipengaruhi oleh fonem / $\mathrm{r} /$ dan ketidakmampuan responden melafalkan deret konsonan velar stop voiceless dan alveolar liquid rhotic plain. Adapun posisi ini terjadi pada tataran antepenultima.

Ujaran /tau/ menjadi /au/, pada proses penghilangan fonem ini terjadi pada area ante penultima. Di mana alveolar stop plain voiceless /t/ tidak dapat dilafalkan sehingga terjadilah penghilangan daerah awal silaba. Melihat morfem yang diujarkan responden ini tidak memiliki makna sama sekali.

Pada tuturan /dua/ responden mengalami gangguan juga sehingga morfem yang diproduksi oleh responden adalah /ua/. Kata ini tidak memiliki makna, sehingga lawan bicara menjadi tidak memahi ujaran itu. 
Fonem /d/ berada pada daerah alveolar stop plain voiced, fonem ini terletak pada tataran ante penultima. Dengan terjadinya peristiwa seperti, penulis menyimpulkan bahwa responden tidak dapat melafalkan fonem alveolar stop plain voiced maupun voiceless. Hal ini dapat dijadikan sebagai bukti atas ketidakmampuan responden dalam memproduksi fonem tersebut.

Pada morfem /sama saja/ juga terjadi pelesapan pada /sa/ sehingga morfem itu menjadi /samaja/ sebenarnya morfem ini dapat saja dimengerti oleh lawan tutur, hal ini disebabkan oleh morfem /sama/. Tapi dalam ilmu neurolinguistik apabila terjadi gangguan dalam bicara hal itu berarti telah terjadi gangguan pada penutur, peristiwa seperti ini disebut juga dengan anamnesis yang dikatakan oleh (Dharmaperwira-Prins, 2004).

Tabel 12 Skema Pengurangan Fonem

\begin{tabular}{|c|c|c|c|c|c|c|c|c|}
\hline No. & Fonem & Jumlah & $\begin{array}{c}\text { Jumlah } \\
\text { Ganguan }\end{array}$ & $\begin{array}{c}\text { Jumlah } \\
\text { yang tidak } \\
\text { terganggu }\end{array}$ & $\begin{array}{c}\text { Posisi } \\
\text { Fonem } \\
\text { yang } \\
\text { terganggu }\end{array}$ & $\begin{array}{c}\text { Posisi } \\
\text { fonem } \\
\text { yang tidak } \\
\text { terganggu }\end{array}$ & Area Artukulasi & $\begin{array}{l}\text { Persentase } \\
\text { Kemampuan } \\
\text { dalam } \\
\text { memproduksi } \\
\text { fonem }\end{array}$ \\
\hline 1 & $/ \mathrm{k} /$ & $\mathrm{k}$ & 1 & - & Depan & $\begin{array}{c}\text { Depan \& } \\
\text { akhir }\end{array}$ & $\begin{array}{l}\text { Velar stop } \\
\text { voiceless }\end{array}$ & $100 \%$ \\
\hline 2 & $/ \mathrm{t} /$ & 2 & 1 & 1 & depan & Tengah & $\begin{array}{l}\text { Alveolar } \\
\text { voiceless }\end{array}$ & $50 \%$ \\
\hline 3 & $/ \mathrm{d} /$ & 2 & 2 & - & $\begin{array}{c}\text { Depan dan } \\
\text { tengah }\end{array}$ & - & Alveolar voiced & $100 \%$ \\
\hline 4 & $/ \mathrm{s} /$ & 3 & 1 & 3 & depan & Tengah & $\begin{array}{c}\text { Fricative central } \\
\text { voiceless }\end{array}$ & $33 \%$ \\
\hline
\end{tabular}

Kelihatan pada tabel 4.12 di atas, fonem /k/ velar stop voiceless terdiri dari 1 fonem, yang berada pada morfem /Kristen/ menjadi /iisten/. Kemudian fonem /t/ terdapat pada morfem /tau/ sementara yang terujar /au/, kemudian pada fonem /d/ ada morfem /dua-dua/, yang terakhir adalah fonem /s/ terdapat pada morfem /saja/.

Kegagalan dalam melafalkan fonem alveolar stop voiceless maupun voiced baik pada posisi penultima maupun pada penultima.

Gambar 1 Diagram Deskripsi Gangguan Bertutur pada Responden 2

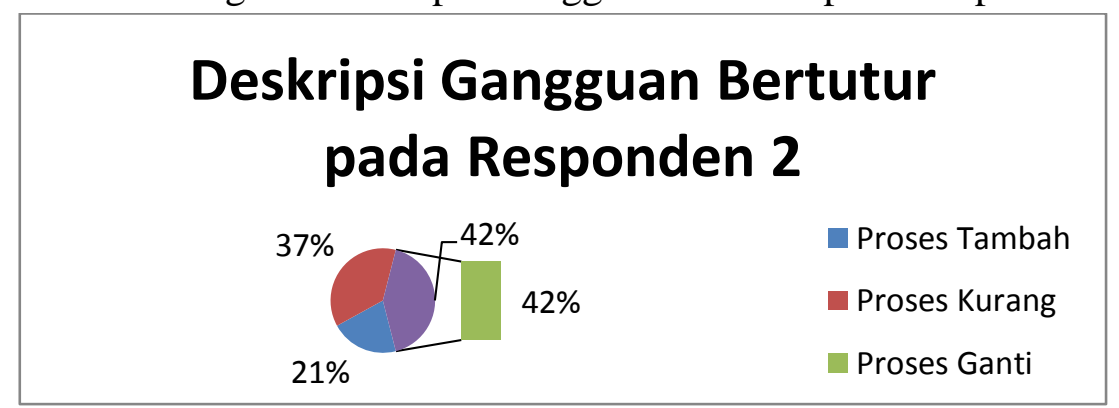

Kelihatan pada diagram di atas terdapat tiga gangguan, gangguan itu sudah termasuk gangguan pada semua posisi. Seperti: pada posisi ante penultima, posisi penultima, dan posisi ultima atau yang terjadi pada posisi awal, tengah dan akhir. 


\section{Simpulan}

Pada penelitian ini ditemukan tiga gangguan dalam bertutur, gangguan tersebut meliputi proses penambahan, proses ganti, dan proses penghilangan. Di sini terdapat dua responden, masing-masing responden mempunyai gangguan bicara yang berbeda-beda. Pada responden pertama gangguan yang paling dominan yang dialami adalah proses pengurangan, sedangkan proses ganti hanya sekali. Sementara itu proses penambahan tidak ditemukan.

Sementara pada responden kedua, proses gangguan yang dialaminya kelihatan lebih lengkap jika dibandingkan dengan responden pertama. Gangguan yang paling dominan yang ditemukan pada proses ganti terdapat enam gangguan, proses kurang terdapat lima gangguan dan yang terakhir proses tambah terdapat 3 masalah.

Sebenarnya penelitian ini adalah penelitian linguistik terapan di mana data yang didapatkan asli hasil diambil langsung pada responden yang mengalami masalah. Jadi penelitian ini murni penelitian linguistik, peneliti barharap peneliti berikutnya dapat melanjutkan penelitian ini supaya penutur dapat berbagi dengan semua orang sehingga tidak ada jurang pemisah antara orang sakit dengan orang sehat.

\section{Ucapan Terima Kasih}

Pada penelitian ini penulis mengucapkan terima kasih banyak kepada Allah, Swt. yang telah memberi kesempatan pada penulis dalam menyelesaikan penelitian ini serta Rektor, LPPM, dan seluruh civitas dosen Universitas Putera Batam yang telah menerima penelitian ini sebagai bagian dari pemenang hibah penelitian peningkatan kapasitas. Rasa terima kasih juga penulis ucapkan pada responden yang telah bersedia diwawancarai.

\section{Daftar Pustaka}

Ahlsen, E. (2006). Introduction to neurolinguistics. Amsterdam: John Benjamins Publishing Company.

Aichert, I., Späth, M., \& Ziegler, W. (2016). The role of metrical information in apraxia of speech. Perceptual and acoustic analyses of word stress. Neuropsychologia, 82, 171178. https://doi.org/10.1016/j.neuropsychologia.2016.01.009

Bonvillian, N. (1977). Language, culture and communication: The meaning of messages. New Jersey: Prentice-Hall, Inc.

Dharmaperwira-Prins, R. (2004). Gangguan-gangguan komunikasi hemisfer kanan dan pemeriksaan komunikasi kanan (PKHK). Jakarta: Jakarta Djambatan.

Johan, Mhd., Susanto, A. (2018). Tataran fonem penderita strok pada masa terapi: Suatu kajian neurolinguistik. Jurnal Kata, 2(2), 192-204.

Johan, Mhd. Susanto, A. (2018). Gangguan berbahasa pada penderita strok suatu kajian: Neurolinguistik. In Snistek 1 (pp. 103-108). Batam: LPPM Universitas Putera Batam.

Johan, M. (2016). Gangguan pelafalan fonem terhadap anak-anak (balita) suatu kajian: Neurolinguistik. BASIS, 4(1).

Johan, M. (2017). Terapan penggunaan fonem pada anak yang berusia di bawah lima tahun :

Suatu kajian neuro linguistik. Cakrawala Bahasa-Jurnal Pendidikan Bahasa Dan Sastra, 6(1), 1-144. 
Kridalaksana, H. (1993). Kamus linguistik. Jakarta: PT. Gramedia.

Leung, J. H., Purdy, S. C., Tippett, L. J., \& Leão, S. H. S. (2017). Affective speech prosody perception and production in stroke patients with left-hemispheric damage and healthy controls. Brain and Language, 166, 19-28. https://doi.org/10.1016/j.bandl.2016.12.001

New, A. B., Robin, D. A., Parkinson, A. L., Duffy, J. R., Mcneil, M. R., Piguet, O., ... Ballard, K. J. (2015). NeuroImage: Clinical altered resting-state network connectivity in stroke patients with and without apraxia of speech. YNICL, 8, 429-439. https://doi.org/10.1016/j.nicl.2015.03.013

Nida, E. A. (1963). Morphology: The descriptive analysis of words (second edi). Michigan: The University of Michigan Press.

Pike, K. L. (1975). Phonemics: A technical for reducing languages to writing. Michigan: The University of Michigan Press.

Polanowska, K. E., \& Pietrzyk-Krawczyk, I. (2016). Post-stroke pure apraxia of speech - A rare experience. Journal of Dermatological Science, 2-8. https://doi.org/10.1016/j.pjnns.2016.08.005

Sastra, G. (2010). Neurolinguistik: Suatu pengantar. Bandung: Alfabeta Bandung.

Sastra, G. (2014). Bahasa dan strok: Andalas University Press.

Sudaryanto. (2015). Metode dan aneka teknik analisis bahasa: Pengantar penelitian wahana kebudayaan secara linguistis. Yogyakarta: Sanata Dharma University Press.

Susan Jerger, Markus F. Damian, Rachel P. McAlpine, H. A. (20170. Visual speech alters the discrimination and identification of non-intact auditory speech in children with hearing loss. International Journal of Pediatric Otorhinolaryngology. https://doi.org/10.1016/j.ijporl.2017.01.009

Trost, J. E., \& Canter, G. J. (1974). Apraxia of speech in patients with Broca's aphasia: A study of phoneme production accuracy and error patterns. Brain and Language, 1(1), 63-79. https://doi.org/10.1016/0093-934X(74)90026-1

Winarsih, S. (2012). Ekspresi tutur anak tuna rungu dalam interaksi di kelas. Universitas Negeri Malang. 